\title{
Complex Roles of Chinese Media: Regional Variation of Party Newspaper's Attitudes towards Government Agencies
}

\author{
By Fangfei Wang * \\ Li Shao
}

\begin{abstract}
In China, Party newspapers, newspapers that are directly run by the various levels of Party agencies, constitute the mainstream media to publish political news about the government and the Party. They are supposed to play the supervising role to monitor the government's performance. However, the effectiveness of such supervising role depends on the relative power, i.e. the hierarchical distance between the newspaper and the targeted government or Party agency. Party newspapers are more critical to the subordinate level of government agencies than the ones with the same or higher level. A comparative content analysis on party newspapers from two cities, Beijing and Guangzhou, confirms that the city-level party newspapers are more critical to their subordinate districts and townships, while more gentle on the city-level government agencies. However, we also discover that Guangzhou Daily casts more criticism onto city-level officials than Beijing Daily does, in that Guangzhou has a more competitive and civic-engaging media environment. This result shows that the regime's expectation of the media's role is affected by local social conditions.
\end{abstract}

Keywords: Chinese media, media roles, party paper

\section{Introduction}

Chinese news media are owned by the ruling Communist Party, but it does not mean that they could not criticize the government. In fact, since the media marketization reform, Chinese media's role to supervise government behavior becomes more and more important. However, media's supervising role is still under the constraint that they are owned and controlled by the Party.

This paper presents a piece of empirical evidence on how political power hovering around Chinese media shapes their supervision role. We inspect a specific kind of media, the "Party newspaper" (Dangbao), directly led by the Party committee (Li \& Liu, 2009). We find that the supervising power of citylevel party newspapers was shaped by the administrative level they are on. The city-level party newspapers in Beijing and Guangzhou are more frequently to criticize the government agencies that have a lower administrative rank, while they are more hesitant to publish stories that criticize the agencies that have a more superior administrative rank. This result confirms that Chinese media's "fourth estate role" is constrained by the political power they possess.

\footnotetext{
* Assistant Professor, Dalian University of Technology, China.

${ }^{\dagger}$ PhD Student, Syracuse University, USA.
} 


\section{Literature Review and Hypotheses Building}

Studies in the perspective of media sociology outline the architecture of the media field and explain news production according to the structural conditions within that field (Benson, 2006; Bourdieu, 2005). According to this study, news production is influenced by both internal factors and external factors of media organization. Internal factors include journalist's cognition of professional role, developing goals of organization. External factors include national communication management system, social and cultural environment, economic forces (Pan, 2005; McQuail, 1992; Shoemaker \& Reese, 1996).

Unlike the western media pursuing social responsibility and trying to keep relatively independent from the political and economic forces, Chinese traditional media, which is constituted by newspapers, magazines, broadcasting and television channels, was gradually taken over by Chinese government or carried out socialist transformation since the foundation of China, and now belongs to a branch of state apparatus, supervised and guided by the Communist Party's Publicity Department (Liu, 1971). The media's political propaganda function determines that it needs to comply with the national or local agenda of the state and the Party ( $\mathrm{Li} \& \mathrm{Liu}, 2009)$. The reform and opening policy in China after 1978, stimulates the gradual relaxing of media environment. With the introduction of media professionalism and the development of journalism education, Chinese media has become more market-oriented, pursuing economic profits and trying to establish a professional code of conduct in order to play a "fourth estate" role in public service and public opinion (Li \& Liu, 2009; Shao, Lu, \& Hao, 2016).

However, since the media is still under the Party's control, the reform of Chinese media is incomplete (Pan, 2005; Li, 2004). Therefore, in the dual logics of the subordination of party-state management and the self-pursuit of professional journalism, the process of Chinese media reform is filled with contradictions and ambiguities (Lee, 1994). Although the media's supervising role on government affairs is growing, its development is still restricted by the political power it has. Previous studies show that the media is only allowed to supervise non-governmental objects (Sun, 2010) or the supervising function is used as a form of clientelism (Lee, He, \& Huang, 2007). Nevertheless, there are few studies noticing that the imbalanced power across different levels of the government could also shape media's supervising pattern. This paper tries to fill this blank by inspecting the variation of media's critiques onto different levels of the government. Specifically, we examine the city-level Party newspapers, which are under the direct control of city party committees. The advantage to inspect party newspapers is that they have a manifest administrative rank. It allows us to observe how the newspapers' supervising power expands or shrinks along with the change of political power, i.e. the administrative rank. Since the newspapers are still under political control, we expect that they are more likely/frequently to supervise the government agencies subordinate to their own level, while fulfill more propaganda obligations for equal-level or higher-level agencies. 
According to this principle, we developed several hypotheses below:

H1. The higher the level of a government is, the more types of news report on it.

H2. The higher the level of a government is, the more likely it will take a more noticeable position on the newspaper pages.

H3. The higher the level of a government is, the larger amount of news articles it will have.

Types, frequency and positions of articles on newspaper pages reflect the degree of emphasis a newspaper places on particular subjects (Ghanem, 1997). The more powerful government agencies could take a more important position in the arrangement of news report and newspaper publication. Therefore, we expect city-level party newspapers pay higher attention to the city-level government agencies in terms of propagandizing their activities.

H4. The lower the level of a government is, the more critical the reports will be.

H5. The lower the level of a government is, the more likely that the news report will suggest that this government should take major responsibility on its misbehaviors.

Emotional propensity and content attributes of coverages reflect media's attitude to government (Entman, 1993; Chen, 2007). When party newspapers have a more advantaged power position against the government agencies they report, the journalists are more likely to hold a critical position to cover the news.

H6. As the subject in a news report, a higher-level government is more likely to become the major source of information.

Sources of information refer to the clues and evidence that the journalists use to compose a news story. Political power also influences how a newspaper weighs the sources of information. Higher-level governments with higher political power could impose their position to the newspapers, while the lowerlevel governments are less capable of influencing the decision of editors and journalists. Therefore, the city-level party newspapers are more likely to report and emphasize the information offered by their equivalent or higher-level governments. 


\section{Methods}

To test these hypotheses, this study makes a content analysis on two party newspapers, Beijing Daily \& Guangzhou Daily, from 2013 to 2014. The unit of analysis is the news reports.

\section{Sample}

We choose Beijing Daily and Guangzhou Daily because Beijing and Guangzhou both have developed newspaper industry but different media ecosystem. The news production and attitudes towards governments of these two Party newspapers are representative to all Chinese Party newspapers.

Beijing is the capital and political center of China. The policies of Beijing Municipal government are heavily influenced by the attitude of the central government. The party newspapers are more conservative in Beijing, compared to the newspapers in other provinces On the other hand, Guangzhou Daily is one of the trailblazers in the reform of Chinese Party newspaper, whose methods and ideas media management are pioneering in the country. Therefore, Guangzhou Daily can represent the latest breakthrough of professionalism among Chinese Party newspapers.

We choose environmental news as the topic in order to make controlled comparison across two newspapers. In recent years environmental pollution has become a serious issue that attracts both the attention of the citizen, the government and thus, the media supervision (Huang \& Liu, 2014a). We sampled the news articles about environmental affairs for two entire years, from Jan $1^{\text {st }}$ 2013 to Dec $31^{\text {th }} 2014$, in order to cover all important time points of Chinese politics, such as the annual national people's conference or the Party Central Committees' annual conference.

Overall, this article collects 615 articles in Beijing Daily and 709 in Guangzhou Daily from Beijing Daily and Guangzhou Daily, in total of 1,324 pieces.

\section{Variables}

We coded the data according to their presentation style, emotion propensity, and content attributes.

\section{Presentation style.}

Article style. According to the type division of reports and the observation of relevant agenda reports, we differentiate (1) news reporting, (2) feature, (3) in-depth report (including exclusive interview and investigative reporting), (4) comment (or review), (5) science and research article, and (6) others.

Page position. In order to facilitate the comparison, this article records all the page numbers of the reports. 


\section{Emotion propensity.}

Emotion Propensity refers to the positions, attitudes, and emotions of reports. This article divides them into three categories: (1) positive; the article holds an optimistic attitude or gives a positive comment to the events and the actions; (2) negative; the article holds a denial attitude or gives a pessimistic comment to the events and the actions; (3) neutral; the report shows no attitudinal tendency to the events and the actions.

\section{Content attributes of reports.}

Sources of information. According to the observation of text, we divide this variable into eight categories: (1) government, (2) social organization, (3) media, (4) enterprise, (5) public opinion leader, (6) the general public, (7) foreigners, and (8) others.

Core subject in the report. This variable refers to the main subjects that involve in the events. According to the observation of relevant articles, we differentiate the subjects into six categories: (1) government, (2) enterprise, (3) civil organization, (4) non-governmental public figure, (5) the public, and (6) international actors. We further coded the government category into four subcategories according to its administrative level: (1) central and provincial government, (2) municipal government, (3) county-level government, and (4) grass-root government (township and under-township level). When the relevant subjects (or government levels) of a report are more than one category, we will choose the most important three subjects (or government levels) as the relevant subjects. Besides, we also coded the highest level of the relevant governments in the reports: 0 (no government mentioned in the report), 1 (grass-root government), 2 (county-level government), 3 (municipal government), 4 (central and provincial government).

Subject behaviors. Before coding this variable, we conduct a pilot analysis on a portion of the sample by reading, analyzing and summarizing the images of subjects presented in the reports. At the end, we summarize 5-10 adjectives which can best embody the images of subjects. On this basis, we coded the subject behaviors into the following categories: (1) absence of efficient policy, (2) economic growth prioritized, (3) poor supervision, (4) weak propaganda, (5) insufficient disclosure, (6) making policy and regulation, (7) enhancing supervision, (8) improving environment, (9) transparent information, (10) scientific development; (11) international cooperation, (12) listening to public opinion, (13) others. 


\section{Results}

\section{Presentation Style on Different Levels of Governments in Party Newspapers}

Types of reports related to governments in party newspapers. In our sample, the Party newspaper reported governments mainly in the form of news brief $(79.1 \%)$, while other forms including feature $(10.7 \%)$, comment $(5.5 \%)$, indepth report $(2.9 \%)$, science and research article $(0.7 \%)$ represent a smaller proportion. This, to some extent, fulfills the typical style of Chinese news reports: focusing on the record of officials' activities and ignoring the evaluation of policy performance, investigative reports and expert news of scientific discoveries (Huang \& Liu, 2014b). The types of reports related to different levels of governments normally comply with such reporting custom (Table 1). Not much differences are seen among different levels of governments, failing to support $\mathrm{H} 1$.

Table 1. Types of Reports Related to Different Levels of Governments

\begin{tabular}{|l|c|c|c|c|c|c|c|}
\hline & $\begin{array}{c}\text { News } \\
\text { reporting }\end{array}$ & Feature & $\begin{array}{c}\text { In-depth } \\
\text { Report }\end{array}$ & Comment & $\begin{array}{c}\text { Science } \\
\text { Articles }\end{array}$ & Others & Total \\
\hline Central/ & 182 & 7 & 7 & 27 & 3 & 0 & 226 \\
Provincial & $(80.5 \%)$ & $(3.1 \%)$ & $(3.1 \%)$ & $(11.9 \%)$ & $(1.3 \%)$ & $(0)$ & $(100 \%)$ \\
\hline Municipal & 702 & 93 & 30 & 51 & 3 & 6 & 885 \\
& $(79.3 \%)$ & $(10.5 \%)$ & $(3.4 \%)$ & $(5.8 \%)$ & $(0.3 \%)$ & $(0.7 \%)$ & $(100 \%)$ \\
\hline County-level & 176 & 42 & 9 & 3 & 1 & 8 & 239 \\
& $(73.6 \%)$ & $(17.6 \%)$ & $(3.8 \%)$ & $(1.3 \%)$ & $(0.4 \%)$ & $(3.3 \%)$ & $(100 \%)$ \\
\hline Grass-root & 42 & 10 & 4 & 1 & 0 & 0 & 57 \\
& $(73.7 \%)$ & $(17.5 \%)$ & $(7.0 \%)$ & $(1.8 \%)$ & $(0)$ & $(0)$ & $(100 \%)$ \\
\hline
\end{tabular}

Notes: The numerical values in the table are the number of reports of certain type related to certain government level; the percentage is the number of reports of certain type in the number of all reports related to certain level of governments. Source: Beijing Daily \& Guangzhou Daily.

Page arrangement of the party newspaper for the reports related to different levels of governments. This article analyzed the relation between the page numbers of reports and the highest levels of related governments. We conduct the correlation analysis of these two variables in Beijing Daily and Guangzhou Daily respectively, and we get a remarkably negative correlation (Table 2). This means the higher the levels of government are, the smaller the page numbers of reports will be. In other words, both of these two newspapers tend to give a more important position to the higher levels of governments - by putting them to the front pages of the newspaper. Thus, $\mathrm{H} 2$ is verified.

Table 2. Pearson Correlation Coefficients for the Edition Positions and the Highest Levels of Related Governments

\begin{tabular}{|l|c|}
\hline & Pearson Correlation Coefficient \\
\hline Beijing Daily & $-0.198^{\mathrm{c}}$ \\
\hline Guangzhou Daily & $-0.156^{\mathrm{c}}$ \\
\hline
\end{tabular}

Notes: ${ }^{\mathrm{a}} \mathrm{p}<0.05,{ }^{\mathrm{b}} \mathrm{p}<0.01,{ }^{\mathrm{c}} \mathrm{p}<0.001$. 


\section{Emotional Propensity of the Reports Related to Different Levels of Governments in Party Newspapers}

The emotional propensity also reflects the attitude of the Party newspapers on different levels of governments. Table 3 presents how the news reports in the two Party newspapers we studied fall into three emotional propensity categories. Overall, the Party newspapers give more positive evaluations than negative evaluations to all levels of the governments. In the sample, the majority of the Emotion propensity of the reports related to governments is either positive or neutral with $45.5 \%$ and $44.2 \%$ respectively. The negative reports (critical reports) only represent $10.4 \%$ in all reports. Second, there are differences between the attitudes of the Party's newspapers towards different levels of governments. As the levels of governments drop, the negative evaluations on governments increase. Therefore, we can conclude that $\mathrm{H} 4$ is tenable.

Table 3. Emotional Propensity of the Reports Related to Different Levels of Governments

\begin{tabular}{|l|c|c|c|c|}
\hline & Positive & Negative & Neutral & Total \\
\hline Central/Provincial & 80 & 23 & 123 & 226 \\
& $(35.4 \%)$ & $(10.2 \%)$ & $(54.4 \%)$ & $(100 \%)$ \\
\hline Municipal & 382 & 79 & 423 & 884 \\
& $(43.2 \%)$ & $(8.9 \%)$ & $(47.9 \%)$ & $(100 \%)$ \\
\hline County-level & 148 & 27 & 63 & 238 \\
& $(62.2 \%)$ & $(11.3 \%)$ & $(26.5 \%)$ & $(100 \%)$ \\
\hline Grass-root & 30 & 15 & 12 & 57 \\
& $(52.6 \%)$ & $(26.3 \%)$ & $(21.1 \%)$ & $(100 \%)$ \\
\hline
\end{tabular}

Notes: The numerical values in the table are the number of the reports in certain emotional propensity related to certain government level; the percentage is the number of reports in certain emotional tones in the number of all reports related to certain level of governments. Source: Beijing Daily \& Guangzhou Daily.

\section{Content Attributes of the Reports Related to Different Levels of Governments in Party Newspapers}

Emphasis of party newspapers on different social subjects. The selection of sources reflects the newspaper's attitude to different actors. The more frequent the newspapers use information from one source, the more important the source is as the newspapers believe. Therefore, in this paper we use information source as a measurement of the importance of the social actors in the newspapers' eyes.

In the Party newspapers, information sources of environmental reports were mostly from the governments $(73.3 \%)$. The second and third most important sources are other media $(21.8 \%)$ and individual citizens. Social organizations, enterprises, public opinion leaders and foreigners take up no more than $1 \%$ of information sources. Government officials are core subjects in $95.4 \%$ of all environmental reports. Enterprises and individual citizens take 
$22.8 \%$ and $15.3 \%$ of the reports. Social organization, public figures and foreigners are the core subjects in around $1 \%$ of articles.

The distributions of information sources and core subjects are consistent with the nature of environmental issue: the government is usually the most important actor and the ultimate source of important policy decisions; other social subjects not only play a limited role, but also lack the authority to attain first-hand information. However, media's reliance on governments in getting information and capturing report objects, also demonstrate the previous assumption: Chinese media are still significantly controlled by political power.

\section{Governments as Sources of Information in Party Newspapers}

City-level Party newspapers have different preference when they choose sources of information among different levels of governments. The central and provincial governments appear as sources in $17.8 \%$ of all the reports. Second, the proportion of the reports of municipal governments, county-level governments and grass-root governments are respectively $69.6 \%, 18.8 \%$ and $4.5 \%$. ANOVA test on "sources of information" and "levels of governments related to the reports" reveals that the levels of governments vary as sources of information significantly (Table 4). Not surprisingly, the main source of citylevel Party newspapers is the government that directly supervises them. When a report involves a certain government agency, the media tend to use government source if the level of the government is high, while use other sources, such as the public and other media when low levels of governments are involved (Table 5). Thus H3 and H6 are validated.

Table 4. ANOVA for the Effects of Sources of Information on the Levels of Governments Related to the Reports

\begin{tabular}{|l|c|c|c|c|c|}
\hline Source of variance & $\begin{array}{c}\text { Sum-of- } \\
\text { squares }\end{array}$ & df & Mean square & $\boldsymbol{F}$ & $\boldsymbol{p}$ \\
\hline Central/Provincial & 3.769 & 6 & 0.628 & 2.743 & 0.013 \\
\hline Municipal & 8.179 & 6 & 1.363 & 6.294 & 0.000 \\
\hline County-level & 6.405 & 6 & 1.067 & 7.421 & 0.000 \\
\hline Grass-root & 3.49 & 4 & 0.872 & 4.538 & 0.002 \\
\hline
\end{tabular}


Table 5. The Relationship Between Sources of Information and the Levels of Governments Related to the Reports

\begin{tabular}{|l|c|c|c|c|c|c|c|c|}
\hline & Government & $\begin{array}{c}\text { Social } \\
\text { Organization }\end{array}$ & Media & Enterprise & $\begin{array}{c}\text { Public } \\
\text { Opinion } \\
\text { Leader }\end{array}$ & $\begin{array}{c}\text { General } \\
\text { Public }\end{array}$ & Foreigners & Total \\
\hline $\begin{array}{l}\text { Central/ } \\
\text { Provincial }\end{array}$ & $\begin{array}{c}178 \\
(78.8 \%)\end{array}$ & 1 & 45 & 0 & 1 & 1 & 0 & 226 \\
& $(0.4 \%)$ & $(19.9 \%)$ & $(0)$ & $(0.4 \%)$ & $(0.4 \%)$ & $(0)$ & $(100 \%)$ \\
\hline Municipal & 678 & 3 & 183 & 3 & 4 & 13 & 1 & 885 \\
& $(76.6 \%)$ & $(0.3 \%)$ & $(20.7 \%)$ & $(0.3 \%)$ & $(0.5 \%)$ & $(1.5 \%)$ & $(0.1 \%)$ & $(100 \%)$ \\
\hline $\begin{array}{l}\text { County- } \\
\text { level }\end{array}$ & 150 & 0 & 65 & 3 & 0 & 21 & 0 & 239 \\
\hline $\begin{array}{l}\text { Grass- } \\
\text { root }\end{array}$ & $(62.8 \%)$ & $(0)$ & $(27.2 \%)$ & $(1.3 \%)$ & $(0)$ & $(8.8 \%)$ & $(0)$ & $(100 \%)$ \\
\hline
\end{tabular}

Notes: The numerical values in the table are the number of the reports from certain sources related to certain government level; the percentage is the number of reports from certain sources in the number of all reports related to certain level of governments. Source: Beijing Daily \& Guangzhou Daily.

\section{Behaviors of Different Levels of Governments in Party Newspapers}

Table 6 shows that the newspapers focus on similar behaviors across different levels of governments. In the background that China's environment issue is deteriorating and the public's demand for pollution relief is increasing, enhancing supervision and fixing the environment are the topics that the media focus. In the reports of higher levels of governments that have more policy-making power, media focuses more on policy making and ideological propaganda. To the grassroot governments that only undertake detailed policy implementation, the newspapers focus more on their policy performance, administrative measurements, and responsiveness to public opinions. For example, more reports focus on "making policy and regulation" and "raising information transparency" when the issues involved municipal governments, while to the grass-root governments, "listening to the public" becomes the main theme. At the same time, Consistent with the emotional propensity to different levels of governments, with the drop of the government level, negative images such as "economy growth first", "poor supervision" and "insufficient disclosure" are increasing. This also confirms H5.

\section{Comparison between the Reports of Beijing Daily and the Reports of Guangzhou Daily}

Do the attitudes of Party newspapers towards governments vary in different cities? To answer this question, we analyze the "emotional propensity" and "sources of information", and we find that there are differences between two newspapers in attitudes towards governments generally $(\mathrm{p}=0.000)$. Beijing Daily tends to give more positive evaluations on governments, with positive reports account for $62.6 \%$ of all reports. While in the reports of Guangzhou Daily, there are more neutral reports $(57.4 \%)$ and negative reports (12.0\%) (Table 7). 
Table 6. Behaviors of Different Levels of Governments in the Reports in Party Newspapers

\begin{tabular}{|l|c|c|c|}
\hline & $\begin{array}{c}\text { Municipal } \\
\text { Government }\end{array}$ & $\begin{array}{c}\text { County-level } \\
\text { Government }\end{array}$ & $\begin{array}{c}\text { Grass-root } \\
\text { Government }\end{array}$ \\
\hline Absence of policy & $4(0.5 \%)$ & $0(0)$ & $0(0)$ \\
\hline Economy growth first & $15(1.7 \%)$ & $2(0.8 \%)$ & $1(1.8 \%)$ \\
\hline Poor supervision & $81(9.2 \%)$ & $24(10.0 \%)$ & $15(26.3 \%)$ \\
\hline Weak propaganda & $3(0.3 \%)$ & $0(0)$ & $0(0)$ \\
\hline Insufficient disclosure & $12(1.4 \%)$ & $1(0.4 \%)$ & $1(1.8 \%)$ \\
\hline Making policy and regulation & $215(24.3 \%)$ & $13(5.4 \%)$ & $2(3.5 \%)$ \\
\hline Enhancing supervision & $439(49.6 \%)$ & $123(51.5 \%)$ & $24(42.1 \%)$ \\
\hline Improving environment & $515(58.2 \%)$ & $155(64.9 \%)$ & $32(56.1 \%)$ \\
\hline Transparent information & $344(38.9 \%)$ & $49(20.5 \%)$ & $8(14.0 \%)$ \\
\hline Scientific development & $182(20.6 \%)$ & $48(20.1 \%)$ & $15(26.3 \%)$ \\
\hline International cooperation & $13(1.5 \%)$ & $0(0)$ & $1(1.8 \%)$ \\
\hline Listening to public opinion & $56(6.3 \%)$ & $27(11.3 \%)$ & $5(8.8 \%)$ \\
\hline Others & $77(8.7 \%)$ & $21(8.8 \%)$ & $14(24.6 \%)$ \\
\hline
\end{tabular}

Notes: The numerical values in the table are the number of the reports in which certain level of governments show certain behavior; the percentage is the number of reports in which certain level of governments show certain behavior in the number of all reports of certain level of governments. Source: Beijing Daily \& Guangzhou Daily.

Table 7. Comparison of the Emotional Tendencies Between the Reports of Beijing Daily and the Reports of Guangzhou Daily

\begin{tabular}{|l|c|c|c|c|}
\hline \multirow{2}{*}{ Beijing Daily } & Positive & Neutral & Negative & Total \\
\cline { 2 - 5 } & 385 & 178 & 52 & 615 \\
\hline \multirow{2}{*}{ Guangzhou Daily } & $(62.6 \%)$ & $(28.9 \%)$ & $(8.5 \%)$ & $(100 \%)$ \\
\cline { 2 - 5 } & 217 & 407 & 85 & 709 \\
\cline { 2 - 5 } & $(30.6 \%)$ & $(57.4 \%)$ & $(12.0 \%)$ & $(100 \%)$ \\
\hline
\end{tabular}

Notes: The numerical values in the table are the number of the reports with certain emotional tendency in certain newspaper; the percentage is the number of reports with certain emotional tendency in certain newspaper in the number of all reports in certain newspaper. Source: Beijing Daily \& Guangzhou Daily.

\section{Discussion}

Through analyzing the characteristics of the reports related to governments in Chinese Party newspapers, we found significant differences between different levels of governments in terms of page position, amount of articles, emotional propensity, sources of information, and subject behaviors. Therefore, this article reveals the present situation of Chinese Party newspapers: although news production of Chinese media is affected by many factors, in consideration of Chinese media's diverse and complex roles in the reports, political power is the key factor. Given that Chinese media is subordinate to the party-state system and gets controlled by the government, Chinese media, represented by Party newspapers, is still under control of the Party agency that directly supervises it. Based on the news production principle of "giving priority to the 
positive report" in the long history, Chinese media is expected to publish positive information in order to create a good image of the government.

Meanwhile, in China's current system of media management, media is subordinate to the equivalent level of government and the higher level of the Party's propaganda department. Accordingly, these governments can both guide report content by means of administration guidance, such as deleting or revising negative content, or serve as information sources to guide the media indirectly. As our analysis result finds, Beijing Daily and Guangzhou Daily are only responsible to municipal governments and governments at higher levels, thus are less critical to these governments. As for county-level governments and grass-root governments, they are less powerful to intervene municipal Party newspapers. Since most below-city-level governments do not have their own newspapers, they need to rely on municipal Party newspapers as the primary channel of propaganda. Thus, their influence on Party newspapers is weak, and Party newspapers are able to supervise these local governments with less political pressures.

In the background that reports of Party newspapers are overall affected by national communication management system, the news production also differs in different areas. By comparing the attitudes of Beijing Daily and Guangzhou Daily towards different levels of governments, we find that Guangzhou Daily is more critical towards the local governments than Beijing Daily. We believe that this is because two cities have totally different social environments: since Beijing is the capital, the political control from the supervising government is stronger, the public has less civil consciousness, the competition of local market of media is weak, and the professionalism is still at an embryonic edge. However, Guangzhou is regarded as the pioneer in China's reforms. The government is more tolerant of negative reports, citizenry political culture is more mature, the awareness of public participation and supervision is stronger, the competition of market of media is more intense, the reform of local media started earlier, and the professionalism among media workers is stronger. The different attitudes towards the governments between Beijing Daily and Guangzhou Daily in their reports may indicate that besides the government control, social environment such as the public's political culture, the level of competition in media market, and the degree of professionalism in media may also influence the news production of Chinese media (Lei, 2013), and this need to be explored in the future research.

\section{Acknowledgements}

The research is supported by the Fundamental Research Funds for the Central Universities, DUT15RC(3)075. 


\section{References}

Benson, R. (2006). News Media as a "Journalistic Field": What Bourdieu Adds to New Institutionalism, and Vice Versa. Political Communication, 23: 187-202.

Bourdieu, P. (2005). The Political Field, the Social Science Field, and the Journalistic Field. In R. D. Benson, \& E. Neveu (Eds.), Bourdieu and the Journalistic Field (29-47). Cambridge; Malden, MA: Polity.

Chen, Y. (2007). Frame analysis: a theoretical concept that needs to be clarified. Journal of International Communication, 4: 19-23.

Entman, R. M. (1993). Framing: toward clarification of a fractured paradigm. Journal of Communication, 43(4): 51-58.

Ghanem, S. (1997). Filling in the Tapestry: The Second Level of Agenda Setting. In M. McCombs, D. L. Shaw, \& D. Weaver (Eds.), Communication and Democracy: Exploring the Intellectual Frontiers in Agenda-setting Theory. Mathwah, NJ: Lawrence Erlbaum Associates.

Huang, H., \& Liu, L. (2014a). The present situation and the optimizing route of environmental communication: A comparative analysis between traditional media and new media. Journal of Journalism \& Communication, 1: 249-256.

Huang, H., \& Liu, L. (2014b). Construction of environmental issues by traditional mainstream media: taking environmental reports of People's Daily from 2003 to 2012 as an example. Journalism \& Communication, 10: 53-65.

Lee, C. C. (1994). Ambiguities and contradictions: Issues in China's changing political communication. Gazette, 53: 7-21.

Lee, C.-C., He, Z., \& Huang, Y. (2007). Party-Market Corporatism, Clientelism, and Media in Shanghai. The Harvard International Journal of Press/Politics, 12(3), 21-42.

Lei, Y. (2013). Uncovering the Roots of the Nationwide Counterpublic Sphere in China (Unpublished doctoral dissertation). The University of Michigan.

Li, L. (2004). Basic characteristics of the current China's Media Reforms. Modern Communication (Journal of Communication University of China), 5: 29-32.

Li, L., \& Liu, L. (2009). 30 years' reform of China's mass media. Asia Europe Journal, 7(3-4), 405-415.

Liu, A. P. L. (1971). Communication and national integration in communist China. Berkeley, CA: University of California Press.

McQuail, D. (1992). Media Performance. London: Sage.

Pan, Z. (2005). Media Change through Bounded Innovations: Journalism in China's Media Reforms. International Communication Association, Annual Meeting (135). New York, USA.

Shao, G., Lu, J., \& Hao, Y. (2016). Assessing China's Media Reform. Asian Perspective, 40(1), 27-50.

Shoemaker, P. J., \& Reese, S. D. (1996). Mediating the Message: Theories of Influences on Mass Media Content. White Plains, NY: Longman.

Sun, W. (2010). Alliance and Tactics among Government, Media Organizations and Journalists: A Description of Public Opinion Supervision in China. Westminster Papers in Communication and Culture, 7(1). http://doi.org/10.16997/wpcc.194 